\title{
Lysyl Oxidase Homolog 2
}

National Cancer Institute

\section{Source}

National Cancer Institute. Lysyl Oxidase Homolog 2. NCI Thesaurus. Code C95874.

Lysyl oxidase homolog 2 (774 aa, $\sim 87 \mathrm{kDa}$ ) is encoded by the human LOXL2 gene. This protein is involved in the regulation of crosslinking in collagens and elastin. 